\title{
ANALISIS BEBAN KERJA UNTUK MENENTUKAN JUMLAH KARYAWAN YANG OPTIMAL DI UNIVERSITAS SANG BUMI RUWA JURAI ( Study Kasus Fakultas Ekonomi )
}

\author{
Rizal Hasbulloh $^{(1)^{*}}, \operatorname{Kuswarak}^{(1)}$, Novalia $^{(1)}$ \\ ${ }^{(1)}$ FE, Universitas Sang Bumi Rua Jura \\ *email: rizalhas20@gmail.com
}

\begin{abstract}
Abstrak. Tujuan penelitian ini adalah untuk mengetahui jumlah beban kerja yang ada di fakultas ekonomi guna untuk menghitung berapakah jumlah karyawan yang optimal untuk menanggung beban kerja tersebut. Masalah yang dihadapi adalah setiap tahun fakultas ekonomi mengalami jumlah mahasiswa yang fluktuatif atau naik turunnya jumlah yang tidak pasti. Begitupun dengan jumlah karyawan yang terus mengikutinya. Jika jumlah karyawan yang optimal dapat diketahui, maka beban kerja juga dapat ditangani, apakah sesui dengan porsi karyawan itu sendiri atau tidak. Pemberian beban kerja yang sesuai dengan karyawan dapat memberikan keoptimalan kualitas pada hasil yang diberikan. Pengumpulan data diperoleh melalui studi lapangan dengan mengunakan metode deskriptif kualitatif. Peneliti medapatkan sumber data dari wawancara, jobdeskription dan dokumentasi. Wawancara dilakukan kepada responden berjumlah 17 orang karyawan fakultas ekonomi universitas sang bumi ruwa jurai. Berdasarkan hasil penelitian menjelaskan bahwa total waktu optimal kerja yang terhitung adalah berjumlah 100.800 menit/ tahun dengan jumlah karyawan yang optimal berjumlah 12 orang. Akan tetapi dikarenakan porsi beban kerja yang berbeda beda, maka jumlah karyawan yang optimal sesuai dengan beban kerja untuk saat ini adalah berjumlah 17 orang karyawan.
\end{abstract}

Kata kunci: Analisis, Beban Kerja, Jumlah Karyawan

Abstract. The purpose of this study was to determine the amount of workload in the economics faculty in order to calculate the optimal number of employees to bear the workload. The problem faced is that every year the faculty of economics experiences a fluctuating number of students or an uncertain number of ups and downs. Likewise with the number of employees who continue to follow him. If the optimal number of employees can be known, then the workload can also be handled, whether in accordance with the portion of the employees themselves or not. Providing workloads that are suitable for employees can provide optimal quality in the results provided. Data collection was obtained through field studies using qualitative descriptive methods. Researchers get data sources from interviews, job descriptions and documentation. Interviews were conducted with 17 respondents from the economics faculty of the Sang Bumi Ruwa Jurai University. Based on the results of the study, it was explained that the total optimal working time calculated was 100,800 minutes/year with the optimal number of employees being 12 people. However, due to the different portion of the workload, the optimal number of employees according to the current workload is 17 employees.

Keywords: Analysis, Workload, Number of Employees

\section{PENDAHULUAN}

Setiap individu pasti membutuhkan pekerjaan. Semakin meningkatnya sumber daya manusia yang membutuhkan pekerjaan, maka diharuskan adanya perusahaan yang akan menampung sumber daya manusia tersebut. Setiap perusahaan mempunyai standar kemampuan karyawan untuk memenuhi kebutuhan dari perusahan itu sendiri karena sumber daya manusia adalah suatu aset yang berharga (Fatmah, 2017), maka diperlukan suatu pengukuran beban kerja bagi setiap tenaga kerja, oleh karena itu dengan adanya pengukuran beban kerja, perusahaan dapat mengetahui 
keoptimalan karyawan dalam menjalankan pekerjaannya. Beban kerja itu sendiri adalah volume pekerjaan yang diberikan kepada karyawan atau tenaga kerja baik berupa mental atau fisik dan menjadi tanggung jawabnya sampai volume pekerjaan tersebut selesai (Julia Anita, Nasir Aziz, 2013).

Seiring berkembangnya zaman dan semakin ketatnya persaingan dunia organisasi untuk mencapai tujuannya, diperlukan sumber daya yang dapat membantu organisasi tersebut untuk mencapai kesuksesannya, salah satunya adalah tenaga kerja. Tenaga kerja merupakan salah satu faktor penting yang harus diperhatikan oleh perusahaan untuk mencapai tujuan (Raharjo et al., 2016). Oleh karena itu dalam hal ini perusahaan dituntut untuk mengelola sumber-sumber daya secara terencana, terutama sumber daya manusia sebagai tenaga pelaksana operasional perusahaan untuk menghasilkan daya guna dan hasil guna dalam setiap kegiatan perusahaan. Dengan demikian perusahaan tidak hanya dapat mempertahankan dan meningkatkan keuntungan yang diperoleh, tetapi juga dapat mampertahankan eksistensinya dalam dunia usaha. Sumber daya manusia sebagai asset organisasi yang tidak dapat disamakan dengan jenis asset lainnya. Hal ini dikarenakan sumberdaya manusia mempunyai karakteristik yang unik dan tidak dimiliki oleh sumberdaya lainnya yaitu: adanya kreativitas yang dimiliki, adanya pola pikir, daya nalar dan penyesuaian terhadap lingkungan.

Salah satu yang perlu dipertimbangkan perusahaan dalam mengatur sistem manajemennya adalah mengoptimalkan sumber daya yang dimiliki. Karena hal tersebut, perusahaan dapat mengetahui bagaimana penggunaan sumber daya yang dimiliki dan pencapaian target maksimum yang dituju. Selain itu, dengan adanya efektivitas, efisiensi, dan produktivitas, perusahaan dapat mengetahui bagaimana optimalisasi sumber daya yang digunakan dan dapat mengetahui pencapaian target yang telah dijalankan oleh perusahaan. Terkait dengan optimalisasi sumber daya ini, hal yang sering dilakukan oleh suatu perusahaan baik industri jasa maupun manufaktur adalah efisiensi dalam hal sumber daya manusia (SDM).

Menurut maskur Kebutuhan sumber daya manusia (SDM) semakin meningkat baik dari segi kualitas maupun kuantitas (Maskur et al., 2020). Untuk mendapatkan SDM yang sesuai dengan kebutuhan perusahaan maka dibutuhkan pengukuran beban kerja sehingga karyawan dapat optimal dalam menjalankan pekerjaannya. Pengukuran beban kerja diperlukan untuk menetapkan waktu bagi seorang karyawan yang memenuhi persyaratan (qualified) dalam menjalankan pekerjaan tertentu pada tingkat prestasi yang telah ditetapkan

Sumber Daya Manusia merupakan segala potensi yang ada pada manusia baik yang berupa akal pikiran, tenaga, ketrampilan, emosi dan sebagainya yang dapat digunakan baik untuk dirinya maupun untuk organisasi atau perusahaan. Beban kerja yang tidak seimbang diakibatkan dengan jumlah mahasiswa yang fluktuatif. Banyaknya mahasiswa juga menjadi salah satu permasalahan yang harus diperhatikan karena jumlah mahasiswa baru yang tidak setabil akan membuat beban kerja bagi setiap karyawan tidak seimbang. Berikut tabel jumlah data mahasiwa dan staf karyawan yang ada di Universitas Sang Bumi Ruwa Jurai dan Fakultas Ekonomi.

\begin{tabular}{lcc}
\multicolumn{3}{c}{ Tabel 1. Jumlah mahasiswa fakultas ekonomi } \\
\hline \multicolumn{3}{c}{ Fakultas Ekonomi } \\
\hline Tahun Ajaran & Jurusan / Prodi \\
\cline { 2 - 3 } & Manajemen & Akuntansi \\
\hline 2016 & 70 & 0 \\
\hline 2017 & 159 & 10 \\
\hline 2018 & 149 & 5 \\
\hline 2019 & 173 & 25 \\
\hline
\end{tabular}




\begin{tabular}{lcc}
\hline 2020 & 134 & 15 \\
\hline Jumlah & 685 & 55 \\
\hline Jumlah Keseluruhan & & 740
\end{tabular}

Dari tabel 1 dapat dilihat bahwa jumlah mahasiswa yang fluktuatif atau mengalami naik turunya jumlah yang tidak tetap dapat mengakibatkan beban kerja yang tidak efektif. Untuk menyelesaikan beban kerja yang optimal, diperlukan juga karyawan yang optimal di setiap bagian. Karena karyawan yang optimal mempengaruhi akan hasil pencapaian. Oleh sebab itu karyawan yang optimal sangat berbengaruh dalam sebuah organisasi ataupun perusahaan.

Menurut Kalammollah (2016), pengukuran beban kerja sangatlah penting karena Pengukuran beban kerja diperlukan untuk menetapkan waktu bagi seorang karyawan yang memenuhi persyaratan (qualified) dalam menjalankan pekerjaan tertentu pada tingkat prestasi yang telah ditetapkan (Nabawi, 2019). Usaha yang efektif dan efisien mengandung arti bahwa output yang dihasilkan oleh setiap karyawan memenuhi apa yang ditargetkan oleh organisasi. Berdasarkan jumlah output atau hasilkerja yang mampu dihasilkan oleh setiap karyawan, dapat diketahui berapa jumlah karyawan yang sesungguhnya diperlukan oleh perusahaan untuk mencapai target

\section{METODE PENELITIAN}

Data yang dipakai pada penelitian ini adalah data primer. Data primer pada penelitian ini adalah bagaimana beban kerja setiap karyawan di fakultas ekonomi apakah terlalu berat atau ringankah, guna untuk penentuan jumlah karyawan yang optimal. Populasi dalam penelitian ini adalah para karyawan Fakultas Ekonomi Universitas Sang Bumi Ruwa Jurai. Karyawan Fakultas Ekonomi Universitas
Sang Bumi Ruwa Jurai berjumalah 17 karyawan, maka pada penelitian ini menggunakan populasi untuk dijadikan sebagai objek penelitian. Dalam analisis data peneliti menggunakan metode Work Load Analysis (WLA)

\section{HASIL DAN PEMBAHASAN}

Jam kerja efektif digunakan untuk pembegian antara waktu penyelesaian kerja dan beban kerja, maka barulah mendapat hasil berupa jumlah karyawan yang optimal. Jam kerja efektif terdiri dari jumlah jam kerja formal dikurangi dengan waktu kerja yang hilang karena tidak bekerja seperti melepas lelah, istirahat makan dan sebagainya. a) jam kerja efektif per hari : 1 hari $\mathrm{x} 7$ jam $=420$ menit. b) jam kerja efektif per minggu : 5 hari $x$ 7 jam $=35$ jam $=2.100$ menit. c) jam kerja efektif per bulan : 20 hari $\times 7$ jam $=140$ jam $=$ 8.400 menit. d) jam kerja efektif per tahun : 240 hari $x 7$ jam $=1.680$ jam $=100.800$ menit.

Seperti yang telah peneliti ungkapkan pada metode analisis di awal tadi, penyelesaian beban kerja yang tidak sama di setiap tugas, ada tugas perhari, perminggu, perbulan dan pertahun. Maka dari itu peneliti menyatakan bahwa total waktu kerja kita ambil tahunan, dengan total kerja efektif adalah 100.800 menit/tahun. 
Tabel 2. Beban Kerja Dekan

\begin{tabular}{|c|c|c|c|c|c|c|}
\hline No & Uraian tugas & $\begin{array}{l}\text { Satuan } \\
\text { hasil }\end{array}$ & $\begin{array}{c}\text { Waktu } \\
\text { penyelesaian }\end{array}$ & $\begin{array}{l}\text { Waktu } \\
\text { kerja } \\
\text { efektif }\end{array}$ & $\begin{array}{l}\text { Total } \\
\text { waktu } \\
\text { kerja }\end{array}$ & $\begin{array}{l}\text { Beban } \\
\text { kerja }\end{array}$ \\
\hline 1 & $\begin{array}{l}\text { Penanggungjawab utama di Fakultas, } \\
\text { pelaksana kebijakan umum, } \\
\text { penetapan peraturan, norma, dll. }\end{array}$ & Kegiatan & 240 Menit & $\begin{array}{l}100.800 \\
\text { Menit }\end{array}$ & 240 & 0,002 \\
\hline 2 & Bertanggungjawab kepada Rektor & Kegiatan & 240 Menit & $\begin{array}{c}100.800 \\
\text { Menit }\end{array}$ & 240 & 0,002 \\
\hline 3 & $\begin{array}{l}\text { membina disiplin para dosen, } \\
\text { karyawan, dan mahasiswa sesuai } \\
\text { peraturan dan perundang-undangan } \\
\text { yang berlaku. }\end{array}$ & Kegiatan & 60 Menit & 420 Menit & 14.400 & 0,14 \\
\hline 4 & $\begin{array}{l}\text { Mengadakan rapat pimpinan } \\
\text { sekurang-kurangnya satu kali dalam } \\
\text { satu bulan dan rapat dosen sekurang- } \\
\text { kurangnya satu kali dalam satu } \\
\text { semester serta rapat staf apabila } \\
\text { sewaktu-waktu dipandang perlu. }\end{array}$ & Kegiatan & 60 Menit & 25.200 Menit & 2.800 & 0,002 \\
\hline 5 & $\begin{array}{l}\text { Terus melakukan pengawasan dan } \\
\text { koordinasi dengan sebaik-baiknya. }\end{array}$ & Kegiatan & 240 Menit & 420 Menit & 57.600 & 0,57 \\
\hline \multicolumn{5}{|c|}{ Total beban kerja dan karyawan yang dibutuhkan } & 75.280 & 0,716 \\
\hline
\end{tabular}

Jadi karyawan yang dibutuhkan untuk jabatan dekan adalah sebanyak 1 orang dengan jumlah beban kerja 0,716 .

Tabel 3. Beban Kerja Wakil Dekan I

\begin{tabular}{|c|c|c|c|c|c|c|}
\hline No & Uraian tugas & $\begin{array}{c}\text { Satuan } \\
\text { hasil }\end{array}$ & $\begin{array}{c}\text { Waktu } \\
\text { penyelesaian }\end{array}$ & $\begin{array}{c}\text { Waktu kerja } \\
\text { efektif }\end{array}$ & $\begin{array}{l}\text { Total waktu } \\
\text { kerja }\end{array}$ & $\begin{array}{l}\text { Beban } \\
\text { kerja }\end{array}$ \\
\hline 1 & $\begin{array}{l}\text { Membuat perencanaan, pelaksanaan dan } \\
\text { pengawasan serta pengem-bangan } \\
\text { pendidikan, penelitian dan pengabdian } \\
\text { kepada masyarakat }\end{array}$ & $\begin{array}{c}\text { Data / } \\
\text { dokumen }\end{array}$ & 60 menit & 420 menit & 14.400 & 0,14 \\
\hline 2 & $\begin{array}{l}\text { Melakukan pembinaan kepada dosen- } \\
\text { dosen dan tenaga peneliti }\end{array}$ & $\begin{array}{c}\text { Data / } \\
\text { dokumen }\end{array}$ & 240 menit & 2.100 menit & 11.520 & 0,11 \\
\hline 3 & $\begin{array}{l}\text { Menyusun program pengembangan daya } \\
\text { nalar mahasiswa bersama dengan Ketua } \\
\text { Program Studi }\end{array}$ & $\begin{array}{c}\text { Data / } \\
\text { dokumen }\end{array}$ & 360 menit & 8.400 menit & 17.280 & 0,04 \\
\hline 4 & $\begin{array}{l}\text { Membuat laporan segala kegiatan kepada } \\
\text { dekan dalam bentuk dokumen }\end{array}$ & $\begin{array}{c}\text { Data / } \\
\text { dokumen }\end{array}$ & 240 menit & 2.100 menit & 11.520 & 0,11 \\
\hline \multicolumn{5}{|c|}{ Total beban kerja dan karyawan yang dibutuhkan } & 54.720 & 0,40 \\
\hline
\end{tabular}

Jadi karyawan yang dibutuhkan untuk jabatan Wakil Dekan I adalah sebanyak 1 orang dengan jumlah beban kerja 0,40.

Tabel 4. Beban Kerja Wakil Dekan II

\begin{tabular}{|c|c|c|c|c|c|c|}
\hline No & Uraian tugas & $\begin{array}{l}\text { Satuan } \\
\text { hasil }\end{array}$ & $\begin{array}{l}\text { Waktu } \\
\text { penyelesaian }\end{array}$ & $\begin{array}{l}\text { Waktu kerja } \\
\text { efektif }\end{array}$ & $\begin{array}{l}\text { Total waktu } \\
\text { kerja }\end{array}$ & $\begin{array}{l}\text { Beban } \\
\text { kerja }\end{array}$ \\
\hline 1 & $\begin{array}{l}\text { Mengelola keuangan dan pembukuan } \\
\text { keuangan. }\end{array}$ & $\begin{array}{l}\text { Data / } \\
\text { dokumen }\end{array}$ & 120 menit & 8.400 menit & 14.440 & 0,014 \\
\hline 2 & $\begin{array}{l}\text { Mengelola administrasi kekaryawanan } \\
\text { seperti daftar urut kepangkatan dosen dan } \\
\text { karyawan serta pengurusan kenaikan } \\
\text { pangkat para dosen dan karyawan. }\end{array}$ & $\begin{array}{l}\text { Data / } \\
\text { dokumen }\end{array}$ & 120 menit & 8.400 menit & 120 & 0,014 \\
\hline 3 & $\begin{array}{l}\text { Mengurus kerumah tanggaan, } \\
\text { memelihara ketertiban karyawan dan } \\
\text { administrasi melalui absensi/kehadiran. }\end{array}$ & Kegiatan & 120 menit & 420 menit & 28.800 & 0,28 \\
\hline
\end{tabular}




\begin{tabular}{|c|c|c|c|c|c|c|}
\hline 4 & $\begin{array}{l}\text { Mengelola data yang berkaitan dengan } \\
\text { bidang administrasi umum, } \\
\text { kekaryawanan, perlengkapan dan } \\
\text { keuangan }\end{array}$ & $\begin{array}{l}\text { Data / } \\
\text { dokumen }\end{array}$ & 180 menit & 100.800 menit & 180 & 0,001 \\
\hline 5 & $\begin{array}{l}\text { Membuat Laporan Segala kegiatan } \\
\text { kepada Dekan dalam bentuk dokumen. }\end{array}$ & $\begin{array}{l}\text { Data / } \\
\text { dokumen }\end{array}$ & 60 menit & 420 menit & 14.440 & 0,14 \\
\hline \multicolumn{5}{|c|}{ Total beban kerja dan karyawan yang dibutuhkan } & 57.980 & 0,449 \\
\hline
\end{tabular}

Jadi karyawan yang dibutuhkan untuk jabatan Wakil Dekan II adalah sebanyak 1 orang dengan jumlah beban kerja 0,57 .

Tabel 5. Beban Kerja Wakil Dekan III

\begin{tabular}{|c|c|c|c|c|c|c|}
\hline No & Uraian tugas & $\begin{array}{c}\text { Satuan } \\
\text { hasil }\end{array}$ & $\begin{array}{c}\text { Waktu } \\
\text { penyelesaian }\end{array}$ & $\begin{array}{c}\text { Waktu kerja } \\
\text { efektif }\end{array}$ & $\begin{array}{l}\text { Total waktu } \\
\text { kerja }\end{array}$ & $\begin{array}{c}\text { Beban } \\
\text { kerja }\end{array}$ \\
\hline 1 & $\begin{array}{l}\text { Membuat perencanaan, pelaksanaan dan } \\
\text { pengawasan serta pengem-bangan } \\
\text { pendidikan, penelitian dan pengabdian } \\
\text { kepada masyarakat }\end{array}$ & $\begin{array}{c}\text { Data / } \\
\text { dokumen }\end{array}$ & 180 menit & 420 menit & 43.200 & 0,42 \\
\hline 2 & $\begin{array}{l}\text { Memproses izin cuti mahasiswa, tugas } \\
\text { belajar dan pertukaran mahasiswa }\end{array}$ & $\begin{array}{c}\text { Data / } \\
\text { dokumen }\end{array}$ & 120 menit & 100.800 menit & 120 & 0,002 \\
\hline 3 & $\begin{array}{l}\text { membuat laporan segala kegiatan kepada } \\
\text { dekan dalam bentuk dokumen }\end{array}$ & $\begin{array}{c}\text { Data / } \\
\text { dokumen }\end{array}$ & 60 menit & 420 menit & 14.400 & 0,14 \\
\hline \multicolumn{5}{|c|}{ Total beban kerja dan karyawan yang dibutuhkan } & $\mathbf{5 7 . 7 5 0}$ & 0,562 \\
\hline
\end{tabular}

Jadi karyawan yang dibutuhkan untuk jabatan Wakil Dekan III adalah sebanyak 1 orang dengan jumlah beban kerja 0,562.

Tabel 6. Beban Kerja Ketua Program Studi Manajemen

\begin{tabular}{|c|c|c|c|c|c|c|}
\hline No & Uraian tugas & $\begin{array}{c}\text { Satuan } \\
\text { hasil }\end{array}$ & $\begin{array}{c}\text { Waktu } \\
\text { penyelesaian }\end{array}$ & $\begin{array}{c}\text { Waktu kerja } \\
\text { efektif }\end{array}$ & $\begin{array}{l}\text { Total waktu } \\
\text { kerja }\end{array}$ & $\begin{array}{c}\text { Beban } \\
\text { kerja }\end{array}$ \\
\hline 1 & $\begin{array}{l}\text { Melaksanakan, memfasilitasi dan } \\
\text { memantau proses pendidikan dan } \\
\text { pengajaran oleh dosen berdasarkan } \\
\text { kurikulum }\end{array}$ & $\begin{array}{c}\text { Data / } \\
\text { dokumen }\end{array}$ & 120 menit & 420 menit & 28.800 & 0,28 \\
\hline 2 & $\begin{array}{l}\text { Menyusun evaluasi diri program studi di } \\
\text { lingkungan program studi manajemen }\end{array}$ & $\begin{array}{c}\text { Data / } \\
\text { dokumen }\end{array}$ & 120 menit & 100.800 menit & 120 & 0,002 \\
\hline 3 & $\begin{array}{l}\text { Membantu pelaksanaan program resource } \\
\text { sharing dalam hal sarana dan prasarana } \\
\text { pendidikan dan sumber daua manusia }\end{array}$ & kegiatan & 60 menit & 420 menit & 14.400 & 0,14 \\
\hline 4 & $\begin{array}{l}\text { Melaksanakan evaluasi dan } \\
\text { pengembangan kurikulum untuk } \\
\text { menjamin kualitass pembelajaran }\end{array}$ & Kegiatan & 120 menit & 2.100 menit & 5.760 & 0,05 \\
\hline 5 & $\begin{array}{l}\text { Membuat laporan segala kegiatan kepada } \\
\text { dekan dalam bentuk dokumen }\end{array}$ & $\begin{array}{c}\text { Data/ } \\
\text { dokumen }\end{array}$ & 60 menit & 420 menit & 14.400 & 0,28 \\
\hline Tota & eban kerja dan karyawan yang dibutuhl & & & & 69.120 & $\mathbf{0 , 8}$ \\
\hline
\end{tabular}

Jadi karyawan yang dibutuhkan untuk jabatan ketua program studi manajemen adalah sebanyak 1 orang dengan jumlah beban kerja 0,8 .

Tabel 7. Beban Kerja Sekretaris Prodi Manajemen

\begin{tabular}{|c|c|c|c|c|c|c|}
\hline No & Uraian tugas & $\begin{array}{c}\text { Satuan } \\
\text { hasil }\end{array}$ & $\begin{array}{c}\text { Waktu } \\
\text { penyelesaian }\end{array}$ & $\begin{array}{c}\text { Waktu kerja } \\
\text { efektif }\end{array}$ & $\begin{array}{l}\text { Total waktu } \\
\text { kerja }\end{array}$ & $\begin{array}{c}\text { Beban } \\
\text { kerja }\end{array}$ \\
\hline 1 & $\begin{array}{l}\text { Membantu tugas ketua prodi dalam } \\
\text { penyelenggaraan pendidikan, penelitian } \\
\text { dan pengabdian kepada masyarakat }\end{array}$ & $\begin{array}{l}\text { Data / } \\
\text { dokumen/ } \\
\text { Kegiatan }\end{array}$ & 240 menit & 420 menit & 57.600 & 0,57 \\
\hline
\end{tabular}




\begin{tabular}{|c|c|c|c|c|c|c|}
\hline 2 & $\begin{array}{l}\text { Menyusun sistem administrasi dan surat } \\
\text { menyurat keluar dan masuk progran studi }\end{array}$ & $\begin{array}{c}\text { Data / } \\
\text { dokumen }\end{array}$ & 60 menit & 420 menit & 14.400 & 0,14 \\
\hline 3 & $\begin{array}{l}\text { Menyusun dan mengusulkan jadwal } \\
\text { perkuliahan dan daftar nama tenaga } \\
\text { pengajar setiap semester kepada ketua } \\
\text { program studi. }\end{array}$ & $\begin{array}{l}\text { Data / } \\
\text { dokumen }\end{array}$ & 60 menit & 2.100 menit & 2.880 & 0,02 \\
\hline \multicolumn{5}{|c|}{ Total beban kerja dan karyawan yang dibutuhkan } & 74.800 & $\mathbf{0 , 7 3}$ \\
\hline
\end{tabular}

Jadi karyawan yang dibutuhkan untuk jabatan sekretaris prodi manajemen adalah sebanyak 1 orang dengan jumlah beban kerja 0,73. Beban kerja sekprodi lebih besar dibandingkan kaprodi dikarenakan selain mengerjakan tugasnya sendiri sekprodi juga diharuskan membantu sebagian tugas kaprodi.

Tabel 8. Beban Kerja Ketua Program Studi Akuntansi

\begin{tabular}{|c|c|c|c|c|c|c|}
\hline No & Uraian tugas & $\begin{array}{c}\text { Satuan } \\
\text { hasil }\end{array}$ & $\begin{array}{c}\text { Waktu } \\
\text { penyelesaian }\end{array}$ & $\begin{array}{c}\text { Waktu kerja } \\
\text { efektif }\end{array}$ & $\begin{array}{l}\text { Total waktu } \\
\text { kerja }\end{array}$ & $\begin{array}{l}\text { Beban } \\
\text { kerja }\end{array}$ \\
\hline 1 & $\begin{array}{l}\text { Melaksanakan, memfasilitasi dan } \\
\text { memantau proses pendidikan dan } \\
\text { pengajaran oleh dosen berdasarkan } \\
\text { kurikulum }\end{array}$ & $\begin{array}{c}\text { Data / } \\
\text { dokumen }\end{array}$ & 60 menit & 420 menit & 28.800 & 0,28 \\
\hline 2 & $\begin{array}{l}\text { Menyusun evaluasi diri program studi di } \\
\text { lingkungan program studi }\end{array}$ & $\begin{array}{c}\text { Data / } \\
\text { dokumen }\end{array}$ & 120 menit & 2.100 menit & 5.760 & 0,05 \\
\hline 3 & $\begin{array}{l}\text { Membantu pelaksanaan progeam } \\
\text { resource sharing dalam hal sarana dan } \\
\text { prasarana pendidikan dan sumber daya } \\
\text { manusia (SDM) }\end{array}$ & Kegiatan & 60 menit & 420 menit & 14.400 & 0,14 \\
\hline 4 & $\begin{array}{l}\text { Mebantu laporan segala kegiatan kepada } \\
\text { Dekan dalam bentuk dokumen }\end{array}$ & $\begin{array}{c}\text { Data/ } \\
\text { Dokumen }\end{array}$ & 60 menit & 420 menit & 14.400 & 0,14 \\
\hline \multicolumn{5}{|c|}{ Total beban kerja dan karyawan yang dibutuhkan } & 63.360 & 0,61 \\
\hline
\end{tabular}

Jadi karyawan yang dibutuhkan untuk jabatan ketua program studi akuntansi adalah sebanyak 1 orang dengan jumlah beban kerja 0,61 .

Tabel 9. Beban Kerja Sekretaris Prodi Akuntansi

\begin{tabular}{|c|c|c|c|c|c|c|}
\hline No & Uraian tugas & $\begin{array}{c}\text { Satuan } \\
\text { hasil }\end{array}$ & $\begin{array}{c}\text { Waktu } \\
\text { penyelesaian }\end{array}$ & $\begin{array}{c}\begin{array}{c}\text { Waktu kerja } \\
\text { efektif }\end{array} \\
\end{array}$ & $\begin{array}{l}\text { Total waktu } \\
\text { kerja }\end{array}$ & $\begin{array}{c}\text { Beban } \\
\text { kerja }\end{array}$ \\
\hline 1 & $\begin{array}{l}\text { Membantu tugas ketua prodi dalam } \\
\text { penyelenggaraan pendidikan, penelitian } \\
\text { dan pengabdian kepada masyarakat }\end{array}$ & $\begin{array}{l}\text { Data / } \\
\text { dokumen/ } \\
\text { kegiatan }\end{array}$ & 120 menit & 420 menit & 28.800 & 0,28 \\
\hline 2 & $\begin{array}{l}\text { Menyusun sistem administrasi dan surat } \\
\text { menyurat keluar dan masuk program } \\
\text { studi }\end{array}$ & $\begin{array}{c}\text { Data / } \\
\text { dokumen }\end{array}$ & 60 menit & 420 menit & 14.400 & 0,14 \\
\hline 3 & $\begin{array}{l}\text { Menyusun dan mengusulkan jadwal } \\
\text { perkuliahan dan daftar nama tenaga } \\
\text { pengajar setiap semester kepada ketua } \\
\text { program studi. }\end{array}$ & $\begin{array}{c}\text { Data / } \\
\text { dokumen }\end{array}$ & 60 menit & 2.100 menit & 2.880 & 0,002 \\
\hline Tota & eban kerja dan karyawan yang dibut & & & & 46.080 & $\mathbf{0 , 4 2}$ \\
\hline
\end{tabular}

Jadi karyawan yang dibutuhkan untuk

jabatan sekretaris prodi akuntansi adalah sebanyak 1 orang dengan jumlah beban kerja 0,42 .

Tabel 10. Beban Kerja Kepala UPM 


\begin{tabular}{|c|c|c|c|c|c|c|}
\hline No & Uraian tugas & $\begin{array}{c}\text { Satuan } \\
\text { hasil }\end{array}$ & $\begin{array}{c}\text { Waktu } \\
\text { penyelesaian }\end{array}$ & $\begin{array}{c}\text { Waktu kerja } \\
\text { efektif }\end{array}$ & $\begin{array}{l}\text { Total waktu } \\
\text { kerja }\end{array}$ & $\begin{array}{l}\text { Beban } \\
\text { kerja }\end{array}$ \\
\hline 1 & $\begin{array}{l}\text { Beranggung jawab sebagai document } \\
\text { control seluruh kegiatan fakultas }\end{array}$ & kegiatan & 120 menit & 420 menit & 28.800 & 0,28 \\
\hline 2 & $\begin{array}{l}\text { Mengembangankan, mensosialisasikan } \\
\text { dan memonitor implementasi perangkat } \\
\text { dan panduan penjamninan mutu melalui } \\
\text { program sistem managemen mutu }\end{array}$ & Kegiatan & 120 menit & 420 menit & 28.800 & 0,28 \\
\hline 3 & $\begin{array}{l}\text { Mengembangkan, mensosialisasikan dan } \\
\text { mengkoordinasikan kegiatan akreditasi } \\
\text { bersama program studi. }\end{array}$ & Kegiatan & 240 menit & 8.400 menit & 11.520 & 0,028 \\
\hline \multicolumn{5}{|c|}{ Total beban kerja dan karyawan yang dibutuhkan } & 69.120 & $\mathbf{0 , 5 8 8}$ \\
\hline
\end{tabular}

Jadi karyawan yang dibutuhkan untuk jabatan Kepala UPM adalah sebanyak 1 orang dengan jumlah beban kerja 0,58.

Tabel 11. Beban Kerja Sekretaris UPM

\begin{tabular}{|c|c|c|c|c|c|c|}
\hline No & Uraian tugas & $\begin{array}{c}\text { Satuan } \\
\text { hasil }\end{array}$ & $\begin{array}{c}\text { Waktu } \\
\text { penyelesaian }\end{array}$ & $\begin{array}{c}\text { Waktu kerja } \\
\text { efektif }\end{array}$ & $\begin{array}{l}\text { Total waktu } \\
\text { kerja }\end{array}$ & $\begin{array}{l}\text { Beban } \\
\text { kerja }\end{array}$ \\
\hline 1 & $\begin{array}{l}\text { Membuat document control seluruh } \\
\text { kegiatan fakultas }\end{array}$ & $\begin{array}{c}\text { Data / } \\
\text { dokumen }\end{array}$ & 180 menit & 420 menit & 43.200 & 0,42 \\
\hline 2 & $\begin{array}{l}\text { Bertanggung jawab membantu } \\
\text { penyusunan dalam pembuatan action \& } \\
\text { budget plan divisi SPMI dan melakukan } \\
\text { review secara berkala atas realisasinya }\end{array}$ & Kegiatan & 120 menit & 8.400 menit & 1.440 & 0,01 \\
\hline 3 & $\begin{array}{l}\text { Membantu mensosialisasikan dan } \\
\text { mengkoordinasikan kegiatan akreditasi } \\
\text { program studi }\end{array}$ & Kegiatan & 60 menit & 420 menit & 14.400 & 0,14 \\
\hline \multicolumn{5}{|c|}{ Total beban kerja dan karyawan yang dibutuhkan } & 59.040 & $\mathbf{0 , 5 7}$ \\
\hline
\end{tabular}

Jadi karyawan yang dibutuhkan untuk jabatan sekretaris UPM adalah sebanyak 1 orang dengan jumlah beban kerja 0,58.

Tabel 12. Beban Kerja Bendahara

\begin{tabular}{|c|c|c|c|c|c|c|}
\hline No & Uraian tugas & $\begin{array}{c}\text { Satuan } \\
\text { hasil }\end{array}$ & $\begin{array}{c}\text { Waktu } \\
\text { penyelesaian }\end{array}$ & $\begin{array}{c}\text { Waktu kerja } \\
\text { efektif }\end{array}$ & $\begin{array}{l}\text { Total waktu } \\
\text { kerja }\end{array}$ & $\begin{array}{c}\text { Beban } \\
\text { kerja }\end{array}$ \\
\hline 1 & $\begin{array}{l}\text { Menyusun program kerja tahunan } \\
\text { subbagian dan mempersiapkan program } \\
\text { kerja tahunan bagian }\end{array}$ & $\begin{array}{c}\text { Data / } \\
\text { dokumen }\end{array}$ & 840 menit & 100.800 menit & 840 & 0,008 \\
\hline 2 & $\begin{array}{l}\text { Membuat daftar gaji dan karyawan, } \\
\text { dosen, dan pembayaran lainnya yang sah. }\end{array}$ & $\begin{array}{c}\text { Data / } \\
\text { dokumen }\end{array}$ & 1.020 menit & 8.400 menit & 12.240 & 0,12 \\
\hline 3 & $\begin{array}{l}\text { Mengerjakan pembukuan dan } \\
\text { pertanggungjawaban keungan }\end{array}$ & $\begin{array}{c}\text { Data / } \\
\text { dokumen }\end{array}$ & 120 menit & 420 menit & 28.800 & 0,28 \\
\hline 4 & $\begin{array}{l}\text { Membuat laporan pelaksanaan program } \\
\text { kerja subbagian }\end{array}$ & $\begin{array}{c}\text { Data/ } \\
\text { dokumen }\end{array}$ & 60 Menit & 420 Menit & 14.400 & 0,14 \\
\hline 5 & $\begin{array}{l}\text { Melayani pembayaran spp mahasiswa } \\
\text { semester akhir }\end{array}$ & kegiatan & 120 Menit & 420 Menit & 28.800 & 0,28 \\
\hline
\end{tabular}




\begin{tabular}{l}
\hline Total beban kerja dan karyawan yang dibutuhkan \\
\hline Jadi karyawan yang dibutuhkan untuk \\
jabatan bendahara adalah sebanyak 1 orang \\
dengan jumlah beban kerja 0,828 .
\end{tabular}

Tabel 13. Beban Kerja Kepala Ruang Baca

\begin{tabular}{|c|c|c|c|c|c|c|}
\hline No & Uraian tugas & $\begin{array}{c}\text { Satuan } \\
\text { hasil }\end{array}$ & $\begin{array}{c}\text { Waktu } \\
\text { penyelesaian }\end{array}$ & $\begin{array}{c}\text { Waktu kerja } \\
\text { efektif }\end{array}$ & $\begin{array}{l}\text { Total waktu } \\
\text { kerja }\end{array}$ & $\begin{array}{c}\text { Beban } \\
\text { kerja }\end{array}$ \\
\hline 1 & $\begin{array}{l}\text { Merencanakan, melakukan pengadaaan } \\
\text { bahan-bahan pustaka setiap tahun }\end{array}$ & $\begin{array}{c}\text { Data / } \\
\text { dokumen }\end{array}$ & 420 menit & 8.400 menit & 5.040 & 0,05 \\
\hline 2 & Membuat perlengkapan buku & $\begin{array}{c}\text { Data / } \\
\text { dokumen }\end{array}$ & 120 menit & 420 menit & 28.800 & 0,28 \\
\hline 3 & Melayani peminjaman buku-buku & $\begin{array}{c}\text { Data / } \\
\text { dokumen }\end{array}$ & 60 menit & 420 menit & 14.400 & 0,14 \\
\hline 4 & $\begin{array}{l}\text { Melayani pengembalian buku-buku } \\
\text { Yang telah dipinjam dan melayani } \\
\text { perpanjang pinjaman buku }\end{array}$ & $\begin{array}{c}\text { Data/ } \\
\text { dokumen }\end{array}$ & 60 Menit & 420 Menit & 14.400 & 0,14 \\
\hline 5 & $\begin{array}{l}\text { Melayani pembayaran spp mahasiswa } \\
\text { semester akhir }\end{array}$ & kegiatan & 60 Menit & 420 Menit & 14.400 & 0,14 \\
\hline Tota & beban kerja dan karyawan yang dibu & & & & 62.640 & 0,61 \\
\hline
\end{tabular}

Jadi karyawan yang dibutuhkan untuk jabatan kepala ruang baca adalah sebanyak 1 orang dengan jumlah beban kerja 0,61 .

Tabel 14. Beban Kerja Kepala Subbagian Akademik/Operator

\begin{tabular}{|c|c|c|c|c|c|c|}
\hline No & Uraian tugas & $\begin{array}{c}\text { Satuan } \\
\text { hasil }\end{array}$ & $\begin{array}{c}\text { Waktu } \\
\text { penyelesaian }\end{array}$ & $\begin{array}{c}\text { Waktu kerja } \\
\text { efektif }\end{array}$ & $\begin{array}{l}\text { Total waktu } \\
\text { kerja }\end{array}$ & $\begin{array}{c}\text { Beban } \\
\text { kerja }\end{array}$ \\
\hline 1 & $\begin{array}{l}\text { Menyusun program kerja tahunan } \\
\text { subbagian akademik dan mempersiapkan } \\
\text { program kerja thaunan bagian. }\end{array}$ & $\begin{array}{c}\text { Data / } \\
\text { dokumen }\end{array}$ & 2.100 menit & 100.800 menit & 2.100 & 0,021 \\
\hline 2 & $\begin{array}{l}\text { Mempersiapkan bahan penyusunan } \\
\text { kalender akademik }\end{array}$ & $\begin{array}{c}\text { Data / } \\
\text { dokumen }\end{array}$ & 420 menit & 8.400 menit & 5.040 & 0,05 \\
\hline 3 & Melakukan administrasi akademik & $\begin{array}{c}\text { Data / } \\
\text { dokumen }\end{array}$ & 60 menit & 420 menit & 14.400 & 0,14 \\
\hline 4 & $\begin{array}{l}\text { Menyelesaikan/mengurus nilai transkrip } \\
\text { akademik mahasiswa }\end{array}$ & $\begin{array}{c}\text { Data/ } \\
\text { dokumen }\end{array}$ & 120 Menit & 420 Menit & 28.800 & 0,28 \\
\hline 5 & $\begin{array}{l}\text { Memberikan pelayanan administrasi } \\
\text { akadmeik kepada mahasiswa yang berupa } \\
\text { Kartu Rencana Studi (KRS) dan Kartu } \\
\text { Hasil Studi (KHS) mahasiswa, Transkrip }\end{array}$ & $\begin{array}{c}\text { Data/ } \\
\text { dokumen }\end{array}$ & 120 Menit & 420 Menit & 28.800 & 0,28 \\
\hline Tot & ban kerja dan karyawan yang dibutu & & & & 79.140 & 0,771 \\
\hline
\end{tabular}

Jadi karyawan yang dibutuhkan untuk jabatan kepala subbagian akademik/operator adalah sebanyak 1 orang dengan jumlah beban kerja 0,771 .

Tabel 15. Beban Kerja Kepala Tata Usaha 


\begin{tabular}{|c|c|c|c|c|c|c|}
\hline No & Uraian tugas & $\begin{array}{c}\text { Satuan } \\
\text { hasil }\end{array}$ & $\begin{array}{c}\text { Waktu } \\
\text { penyelesaian }\end{array}$ & $\begin{array}{c}\text { Waktu kerja } \\
\text { efektif }\end{array}$ & $\begin{array}{l}\text { Total waktu } \\
\text { kerja }\end{array}$ & $\begin{array}{c}\text { Beban } \\
\text { kerja }\end{array}$ \\
\hline 1 & $\begin{array}{l}\text { Menyusun program kerja tahunan bagian } \\
\text { dan mempersiapkan penyusunan program } \\
\text { kerja thaunan fakultas. }\end{array}$ & $\begin{array}{c}\text { Data / } \\
\text { dokumen }\end{array}$ & 2.100 menit & 100.800 menit & 2.100 & 0,02 \\
\hline 2 & $\begin{array}{l}\text { Melakukan evaluasi pelaksanaan tugas- } \\
\text { tugas sub bagian umum dan } \\
\text { perlengkapan, sub bagian administrasi } \\
\text { dan keuangan, sub bagian }\end{array}$ & $\begin{array}{c}\text { Data / } \\
\text { dokumen }\end{array}$ & 240 Menit & 420 Menit & 57.600 & 0,57 \\
\hline 3 & $\begin{array}{l}\text { Mengurus penyelenggaraan rapat-rapat di } \\
\text { fakultas ekonomi }\end{array}$ & Kegiatan & 120 Menit & 2.100 Menit & 5.760 & 0,05 \\
\hline 4 & $\begin{array}{l}\text { Menyusun laporan pelaksanaan program } \\
\text { kerja bagian dan mempersiapkan } \\
\text { penyusunan laporan pelaksanaan program } \\
\text { kerja fakultas }\end{array}$ & $\begin{array}{c}\text { Data/ } \\
\text { dokumen }\end{array}$ & 2.100 Menit & 8.400 Menit & 25.200 & 0,25 \\
\hline \multicolumn{5}{|c|}{ Total beban kerja dan karyawan yang dibutuhkan } & 90.660 & $\mathbf{0 , 8 9}$ \\
\hline
\end{tabular}

Tabel 16. Beban Kerja staf akademik

\begin{tabular}{|c|c|c|c|c|c|c|}
\hline No & Uraian tugas & $\begin{array}{c}\text { Satuan } \\
\text { hasil }\end{array}$ & $\begin{array}{c}\text { Waktu } \\
\text { penyelesaian }\end{array}$ & $\begin{array}{c}\text { Waktu kerja } \\
\text { efektif }\end{array}$ & $\begin{array}{l}\text { Total waktu } \\
\text { kerja }\end{array}$ & $\begin{array}{l}\text { Beban } \\
\text { kerja }\end{array}$ \\
\hline 1 & $\begin{array}{l}\text { Staf membantu pelaksanaan tugas-tugas } \\
\text { subbagian dan bertanggungjawab } \\
\text { langsung kepada kepala subbagian dan } \\
\text { kepada kepala bagian tata usaha }\end{array}$ & $\begin{array}{c}\text { Data / } \\
\text { dokumen }\end{array}$ & 60 menit & 420 menit & 14.400 & 0,14 \\
\hline 2 & $\begin{array}{l}\text { Mendistribusikan dan bertugas ekspedisi } \\
\text { surat menyurat fakultas }\end{array}$ & $\begin{array}{c}\text { Data / } \\
\text { dokumen }\end{array}$ & 120 Menit & 420 Menit & 28.800 & 0,28 \\
\hline 3 & $\begin{array}{l}\text { Staf membantu subbagian } \\
\text { akadmeik/operator dalam memberikan } \\
\text { pelayanan transkrip dan khs }\end{array}$ & $\begin{array}{c}\text { Data / } \\
\text { dokumen }\end{array}$ & 120 Menit & 420 Menit & 28.800 & 0,28 \\
\hline Tota & ban kerja dan karyawan yang $d$ & & & & 72.000 & $\mathbf{0 , 7}$ \\
\hline
\end{tabular}

Jadi karyawan yang dibutuhkan untuk jabatan staf akademik adalah sebanyak 1 orang dengan jumlah beban kerja 0,7 .

Tabel 17. Beban Kerja staf umum

\begin{tabular}{|c|c|c|c|c|c|c|}
\hline No & Uraian tugas & $\begin{array}{c}\text { Satuan } \\
\text { hasil }\end{array}$ & $\begin{array}{c}\text { Waktu } \\
\text { penyelesaian }\end{array}$ & $\begin{array}{c}\text { Waktu kerja } \\
\text { efektif }\end{array}$ & $\begin{array}{l}\text { Total waktu } \\
\text { kerja }\end{array}$ & $\begin{array}{c}\text { Beban } \\
\text { kerja }\end{array}$ \\
\hline 1 & $\begin{array}{l}\text { Mempersiapkan ruang kelas untuk } \\
\text { pembelajaran, seminar, ujian } \\
\text { skripsi,rapat, dan acara fakultas }\end{array}$ & Kegiatan & 120 menit & 540 menit & 28.800 & 0,22 \\
\hline 2 & $\begin{array}{l}\text { Mempersiapkan dan menyediakan } \\
\text { konsumsi tamu, dosen, dan karyawan, } \\
\text { melaksanakan tugas tertentu sesuai } \\
\text { permintaan dekan, wakil dekan, dan } \\
\text { kepala prodi. }\end{array}$ & Kegiatan & 420 Menit & 540 Menit & 100.800 & 0,78 \\
\hline \multicolumn{5}{|c|}{ Total beban kerja dan karyawan yang dibutuhkan } & 129.600 & 1 \\
\hline
\end{tabular}

Jadi karyawan yang dibutuhkan untuk jabatan petugas kebersihan adalah sebanyak 1 orang dengan jumlah beban kerja 1. 
Tabel 18. Beban Kerja Kepala Tata Usaha

\begin{tabular}{|c|c|c|c|c|c|c|}
\hline No & Uraian tugas & $\begin{array}{c}\text { Satuan } \\
\text { hasil }\end{array}$ & $\begin{array}{c}\text { Waktu } \\
\text { penyelesaian }\end{array}$ & $\begin{array}{c}\text { Waktu kerja } \\
\text { efektif }\end{array}$ & $\begin{array}{l}\text { Total waktu } \\
\text { kerja }\end{array}$ & $\begin{array}{l}\text { Beban } \\
\text { kerja }\end{array}$ \\
\hline 1 & $\begin{array}{l}\text { Menyusun program kerja tahunan bagian } \\
\text { dan mempersiapkan penyusunan program } \\
\text { kerja thaunan fakultas. }\end{array}$ & $\begin{array}{c}\text { Data / } \\
\text { dokumen }\end{array}$ & 2.100 menit & 100.800 menit & 2.1000 & 0,02 \\
\hline 2 & $\begin{array}{l}\text { Mendistribusikan dan bertugas ekspedisi } \\
\text { surat menyurat fakultas }\end{array}$ & $\begin{array}{c}\text { Data / } \\
\text { dokumen }\end{array}$ & 60 Menit & 420 Menit & 14.400 & 0,14 \\
\hline 3 & $\begin{array}{l}\text { Merekapitulasi Absensi dosen dan } \\
\text { karyawan fakultas }\end{array}$ & $\begin{array}{c}\text { Data / } \\
\text { dokumen }\end{array}$ & 2.100 Menit & 8.400 Menit & 25.000 & 0,25 \\
\hline 4 & $\begin{array}{l}\text { Membuat laporan kegiatan dan } \\
\text { mendokumentasikannya }\end{array}$ & $\begin{array}{c}\text { Data/ } \\
\text { dokumen }\end{array}$ & 60 Menit & 2.100 Menit & 2.880 & 0,02 \\
\hline \multicolumn{4}{|c|}{ Total beban kerja dan karyawan yang dibutuhkan } & & 56.680 & 0,55 \\
\hline $\begin{array}{l}\text { jab } \\
\text { aka } \\
\text { den }\end{array}$ & $\begin{array}{l}\text { Jadi karyawan yang dibutuk } \\
\text { an kepala } \\
\text { emik/operator adalah sebany } \\
\text { an jumlah beban kerja } 0,771 \text {. }\end{array}$ & $\begin{array}{l}\text { an untu } \\
\text { ubbagia } \\
\text { x oran }\end{array}$ & & & & \\
\hline
\end{tabular}

Gambar 1. Diagram Beban Kerja Optimal

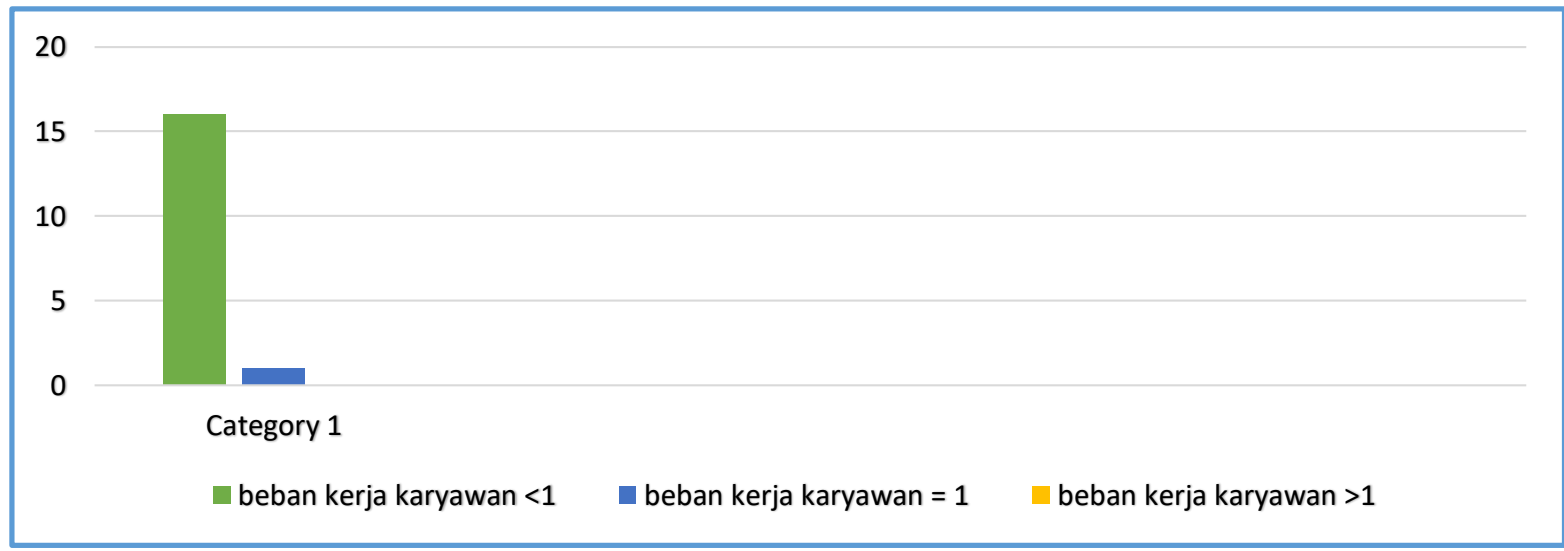

Pada penelitian sebelumnya

Kalamollah, Linda Eka Anggraini 2016 (Analisis Beban Kerja Untuk Menentukan Jumlah Karyawan Yang Optimal Pada Koperasi Pesantren Binaan Pemeritah Surabaya) mendapatkan 4 karyawan optimal di bagian tabulator, 6 karyawan di bagian adhoc, 4 karyawan di bagian HRD dan trainer, dan 8 karyawan di bagian umum. Linda Eka Anggraini, Rony Prabowo 2015 (Analisis Beban Kerja Untuk Menentukan Jumlah Karyawan Yang Optimal Pt. Sanjayautama Lestari Surabaya) mendapatkan 4 karyawan optimal di bagian tabulator, 6 karyawan di bagian adhoc, 4 karyawan di bagian HRD dan trainer. Pada penelitian ini, penulis mendapatkan hasil yaitu pendapatan 1 karyawan di setiap bagian, akan tetapi hanya 1 karyawan yang memiliki beban kerja sesuai dengan jam kerja optimal.

Pada penelitian ini membahas tentang analisis beban kerja guna untuk mengukur berapakah jumlah karyawan yang optimal di Fakultas Ekonomi Universitas Sang Bumi Ruwa Jurai. Penelitian ini melibatkan semua anggota struktural fakultas ekonomi yang berjumlah 
17 orang. Setiap instansi memiliki beban kerja yang berbeda-beda, tetapi memiliki jam kerja yang sama yaitu 7 jam per hari akan tetapi dalam kasus ini kita akan bulatkan waktu kedalam satuan menit dikarenakan kebanyakan beban kerja dikerjakan dalam satuan menit. Maka dari itu waktu kerja yang efektif di fakultas ekonomi adalah 420 menit dalam satu hari, 2.100 menit dalam satu minggu, 8.400 menit dalam satu bulan, dan 100.800 menit dalam satu tahun. Akan tetapi ada satu pengecualian. Untuk beban kerja petugas kebersihan memiliki jam kerja yang lebih banyak, yaitu 129.600 menit dalam satu tahun atau lebih mudahnya waktu kerja petugas kebersihan mempunyai jam kerja 2 jam lebih banyak dibandingkan dengan karyawan lainnya.

Pada pembahasan penelitian ini penulis menggunakan Metode Word Load Analisis dan menggunakan KEP/75/M.PAN/7/2004, disamping itu peneliti menggunakan data yang bersumber dari jobdeskripsion dan wawancara secara langsung kepada informan di Fakultas Ekonomi Universitas Sang Bumi Ruwa Jurai. Jobdeskripsion digunakan sebagai rujukan utama tugas dan tanggung jawab karyawan, sebagai perbandingan dilakukan wawancara secara langsung untuk mendapatkan informasi lebih. Selain itu, peneliti juga melakukan pengamatan atau survey sebelum wawancara dilakukan guna untuk mencari informasi langsung, seperti apakah kegiatan dan situasi di fakultas ekonomi.

Penelitian dilakukan bukan bermaksud untuk mengurangi atau mencabut hak kerja seseorang, melainkan untuk mengetahui efektivitasan kerja dan tanggungan seorang karyawan dalam menjalankan tugas dan menyelesaikan beban kerja yang mereka tanggung. Karyawan yang yang memiliki beban kerja yang berlebihan akan mengakibatkan ketidak efektivan dalam menjalankan kerja.
Maka dari itu selain untuk mengetahui beban kerja yang optimal, penelitian ini juga untuk melihat apakah ada karyawan yang memiliki beban kerja yang melebihi batas kemampuan atau melebihi takaran beban kerja.

\section{KESIMPULAN}

Berdasarkan hasil penelitian dan analisi data yang telah dilakukan maka dapat ditarik simpulan bahwa terdapat 17 orang karyawan di fakultas ekonomi Universitas Sang Bumi Ruwa Jurai, akan tetapi kebanyakan mempunyai beban kerja yang kurang efektif, terhitung ada 16 karyawan yang mempunyai beban kerja di bawah waktu kerja efektiv, hanya 1 orang karyawan yang memiliki beban kerja produktif.

Jumlah karyawan yang opimal di fakultas ekonomi jika menghitung dari beban kerja adalah sebanyak 12 orang karyawan. Akan tetapi dikarenakan volume kerja yang berbeda beda, maka setiap bagian ditetapkan mendapat karyawan sebanyak 1 orang. jadi total karyawan di fakultas ekonomi adaah sebanyak 17 orang.

\section{DAFTAR PUSTAKA}

Astianto, Anggit. 2014. Pengaruh Stres Kerja Dan Beban Kerja Terhadap Kinerja Karyawan PDAM Surabaya. Surabaya. Jurnal Ilmu Dan Riset Manajemen.

Eka Anggraeni, Linanda. 2015. Analisis Beban Kerja Untuk Menentukan Jumlah Karyawan Optimal (Studi Kasus : Pt. Sanjayatama Lestari Sirabaya). Seminar Nasional Sains dan Teknologi Terapan III. Surabaya.

Fatmah, D. (2017). Pengaruh Karakteristik Pekerjaan dan Kompetensi Karyawan terhadap Kinerja Karyawan pada CV. Percetakan Fajar Mojokerto. Jurnal Samudra Ekonomi Dan Bisnis, 8(2), 700-709. 
https://doi.org/10.33059/jseb.v8i2.428

Julia Anita, Nasir Aziz, M. Y. (2013). pengaruh penempatan dan beban kerja terhadap motivassi kerja dan dampaknya pada prestasi kerja pegawai dinas tenaga kerja dan mobilitas penduduk aceh. Jurnal Manajemen Pascasarjana Universitas Syiah Kuala, 2(1), 12.

Kalammollah. 2016. Analisis Beban Kerja Untuk Menentukan Jumlah Karyawan Optimal Pada Koperasi Pesantren (Kopontren) Binaan Pemerintah (Pemkot) Surabaya. Prosiding Seminar Nasional Ekonomi dan Bisnis \& Call For Paper FEB UMSIDA. Surabaya.

Maskur, R., Sumarno, Rahmawati, Y., Pradana, K., Syazali, M., Septian, A., \& Palupi, E. K. (2020). The effectiveness of problem based learning and aptitude treatment interaction in improving mathematical creative thinking skills on curriculum 2013. European Journal of Educational Research, 9(1), 376-383. https://doi.org/10.12973/eu-jer.9.1.375

Nabawi, R. (2019). Pengaruh Lingkungan Kerja, Kepuasan Kerja dan Beban Kerja Terhadap Kinerja Pegawai. Maneggio: Jurnal Ilmiah Magister Manajemen, 2(2), 170-183. https://doi.org/10.30596/maneggio.v2i 2.3667

Raharjo, S., Paramita, D. P., \& Warso, M. (2016). Pengaruh kemampuan kerja, pengalaman dan pelatihan terhadap produktivitas kerja karyawan dengan kompetensi kerja sebagai variabel intervening. Journal of Management, 2(2), 1-13. 